\title{
Analysis of Stress and Fracture Strength of Zirconia Implants after Cyclic Loading
}

\author{
Diogo Rodrigues Cruvinel ${ }^{a}$, Renata Espíndola Silveira ${ }^{a}$, Rodrigo Galo ${ }^{b}$ Carla Cecilia Alandia-Román ${ }^{a}$, \\ Fernanda de Carvalho Panzeri Pires-de-Souza ${ }^{a}$, Heitor Panzeri ${ }^{a}$ \\ ${ }^{a}$ Departamento de Materiais Odontológicos e Prótese, Faculdade de Odontologia de Ribeirão Preto, \\ Universidade de São Paulo - USP, Av. Do Café, s/n, Monte Alegre, \\ CEP 14040-904, Ribeirão Preto, SP, Brazil \\ ${ }^{b}$ Departamento de Odontologia, Universidade Federal dos Vales do Jequitinhonha e Mucuri - UFVJM \\ Rua da Glória, 187, Centro, CEP 39100-000, Diamantina, MG, Brazil
}

Received: July 30, 2015; Revised: August 24, 2015

\begin{abstract}
The aim of this study was to manufacture a new zirconia implant (Y-TZP) and to evaluate the fracture strength and stresses generated after cyclic loading compared to titanium implants. Thirty-three zirconia and titanium implants were fabricated. The stress generated around the implants was observed by photoelastic analysis. The implants were then separated into groups $(n=10)$ : Control (no treatment), mechanical fatigue and thermomechanical fatigue. All groups were submitted to a single cantilever flexure test to measure the material fracture strength. The results (2-way ANOVA, Bonferroni test, $\mathrm{p}<.05$ ) showed no statistically significant difference in the stresses generated between the zirconia and titanium implants. Titanium implants showed higher fracture strength than the zirconia implants, a property that was not altered by fatigue applied. It was concluded that stress distribution was similar for $\mathrm{Zr}$ and $\mathrm{Ti}$ and mechanical and thermomechanical fatigue had no influence on the fracture strength of the implants tested.
\end{abstract}

Keywords: implant, Yttria-doped zirconia, cyclic loading, titanium, photoelasticity

\section{Introduction}

The exclusive treatment using titanium dental implants must be critically viewed since there are population groups who present numerous diseases related to the use of metals, such as sensitivity, titanium allergy and allergy to the by-products of titanium released in the body ${ }^{1}$. Furthermore, the use of dental implants in the esthetic zone is a challenge, particularly in patients who present with thin peri-implant gingival tissue, gingival smile or high gingival smile line, and in cases of bone resorption followed by gingival recession with implant exposure ${ }^{2,3}$.

Based on the necessity for aesthetic reconstructions, anti-allergic biomaterials and requirements of metal-free treatments for these patients, many studies have been proposed, particularly those relating to zirconia ceramics due to their favorable aesthetic, mechanical, physical and chemical properties ${ }^{4-8}$.

Zirconia is radiopaque and because of its color, similar to that of the natural tooth, it is the material of choice for aesthetically critical areas of the mouth ${ }^{6}$. Studies ${ }^{7,8}$ have demonstrated that the material appears to be capable of withstanding loads over the long term and its biocompatibility as a dental implant material has also been demonstrated in vitro and in clinical investigations ${ }^{9}$.

However, most studies are limited to the evaluation of the market available zirconia implants compared with titanium implants, which do not have the same design. Thus, by designing a new dental implant, the aim of the

*e-mail: ferpanzeri@usp.br study was to analyze the stresses generated and fracture strength of identical design zirconia and titanium implants after mechanical and/or thermal fatigue.

\section{Experimental}

To conduct the study, zirconia ( $\mathrm{Zr}$ ) and grade 4 titanium (Ti) implants with the same size and thread profiles were designed and fabricated.

For $\mathrm{Zr}$ implants, the procedure was performed in four stages: press forming, pre-sintering, milling and sintering. First, zirconia powder was molded into a metal cylinder die ( $8 \mathrm{~mm}$ diameter) by uniaxial press forming at a pressure of $\sim 170 \mathrm{Kgf}$, then the obtained cylinders were pre-sintered in a furnace (Jung Furnace, Model 0916 - Blumenau - SC - Brazil) at a heating rate of $1{ }^{\circ} \mathrm{C} / \mathrm{min}$ to $850{ }^{\circ} \mathrm{C}$. After pre-sintering stage, the implant macrostructure was design and the cylinders were milled using a CAD/CAM (Computer-aided design/ Computer-aided manufacturing) system (CNC Veker milling machine - Model FEL-1860 ENC, Vinhedo - SP - Brazil). Finally, the milled implants were sintered in a furnace at $1450{ }^{\circ} \mathrm{C}$.

Twenty percent shrinkage occurs during sintering, therefore, a $20 \%$ expansion was programmed during the CAD process in order to compensate pre-sintered zirconia's dimensional changes.

To determine the final macrostructure of the implant, preliminary tests were conducted and several $\mathrm{Zr}$ prototypes were obtained until the final design was approved and 
developed with a diameter of $4 \mathrm{~mm}$ and overall length of $15 \mathrm{~mm}$ (Figure 1). This was considered the convenience model for the fabrication and reproducibility of the implants.

For titanium implants, grade 4 titanium bars (Realum Ind. Com Metais Puros e Ligas Ltda - São Paulo, SP, Brazil) measuring $4.76 \mathrm{~mm}$ in diameter were cut and machined following the same features as the $\mathrm{Zr}$ implants (Figure 2), thus obtaining the Ti prototype. Thirty-three implants were fabricated.

Photoelastic analysis of stress transfer was used to qualitatively and quantitatively verify the stress generated around the materials studied by applying a centric static load of $200 \mathrm{~N}$ with an ovoid tip.

For the analysis, the implants $(n=3)$ were embedded in photoelastic resin without any interposed material to simulate osseointegration. In addition to the implants, cylinders made of materials with the same dimensions $(15 \mathrm{~mm} \times 4.7 \mathrm{~mm})$ as the implants, but without thread spirals, were obtained to analyze whether the difference in force distribution among $\mathrm{Zr}$ and $\mathrm{Ti}$ implants occurred solely due to the property of the material or due to different shapes of implant designs.

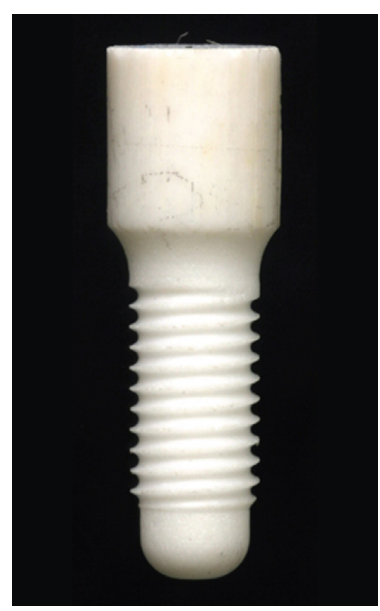

Figure 1. Zr prototype with macrostructure of rounded tip and apex profile.

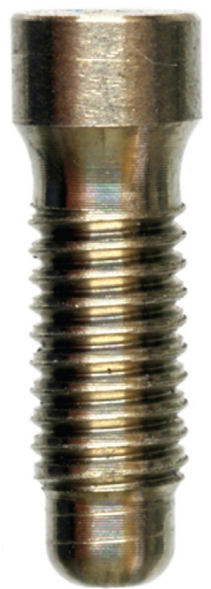

Figure 2. Ti implant with macrostructure of rounded tip and apex profile equal to $\mathrm{Zr}$ implant.
For the qualitative photoelastic analysis, the polariscope was adjusted to circular polarization mode and the pattern of distribution of the isochromatic fringes was observed, in which the larger the number of fringes and the nearer they are the greater is stress intensity and stress concentration, respectively.

For the quantitative photoelastic analysis, the polariscope was adjusted to linear polarization mode. Two points in the cervical region and three points in the apical region of each cylinder and implant were analyzed, totaling 5 points for quantitative readings per specimen.

The values of fringe order (n) were calculated at each point by reading the fringe orders displayed on the photoelastic model using the Senarmont method ${ }^{10}$.

To test mechanical and thermomechanical fatigue, the Zr and Ti implants $(n=30)$ were embedded in polyurethane using a device coupled to the shaft of a parallelometer (Figure 3), which allowed the inclusion at an angle of $30^{\circ}$, following the ISO standard $14081^{11}$.

After the implants had been embedded, they were randomly separated into 3 groups $(n=10)$ according to the type of treatment to which they were submitted: $\mathrm{Ti} / \mathrm{Zr}$ Groups - Control; TiM/ZrM Groups -mechanical fatigue; TiTM/ZrTM Groups - thermomechanical fatigue.

Mechanical fatigue (ERIOS Equipamentos Técnicos e Científicos Ltda. São Paulo - SP - Brazil) was performed at $37{ }^{\circ} \mathrm{C}$ and $133 \mathrm{~N}^{12}$ corresponding to the bite force in the region of anterior teeth in patients with normal occlusion. Each specimen was submitted to 2 million chewing cycles at a rate of $2 \mathrm{~Hz}^{11}$.

The TiTM and ZrTM Groups were submitted to the same mechanical test plus thermocycling at temperatures ranging from $5{ }^{\circ} \mathrm{C}, 37^{\circ} \mathrm{C}$ and $55^{\circ} \mathrm{C}$. Each temperature range remained in contact with the specimen for 35 seconds and each specimen was submitted to a total of 5,714 temperature cycles.

After mechanical and thermomechanical fatigue tests, the fracture strength of the specimens was determined by a single cantilever flexure test, in which the load was applied in the

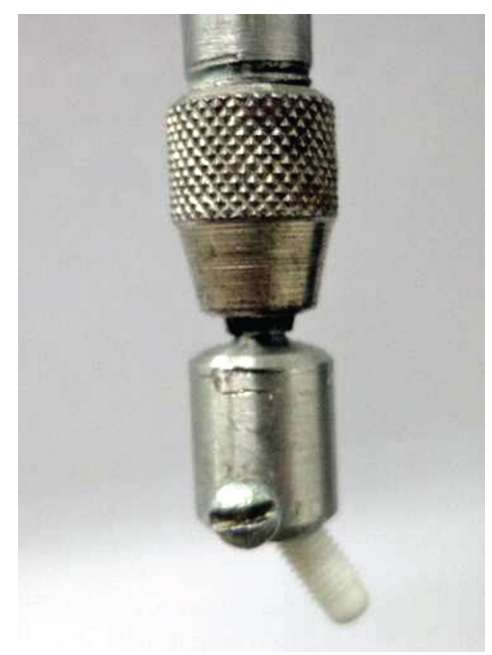

Figure 3. Device to insert implants coupled to the parallelometer used to insert implants in polyurethane resin at an angle of $30^{\circ}$. 
free-end coronal extension of the implant (universal testing machine (EMIC-EMIC DL2000 Equipamentos e Sistemas de Ensaio LTDA. - Pinhais - PR - Brazil) at a crosshead speed of $0.5 \mathrm{~mm} / \mathrm{s}^{[10]}$. For this, implants remained embedded in polyurethane at an angle of $30^{\circ}$ in order to simulate the functional loading of an endosseous dental implant body and its coronal portion under "worst case" conditions.

Fracture strength was calculated according to the Formula 1:

$\sigma=\mathrm{P} / \mathrm{A}$

where $\mathrm{P}$ is the maximum force applied ( $\mathrm{kgf}), \mathrm{A}$ is the cross-sectional area $\left(\mathrm{cm}^{2}\right)$ of the fracture region calculated by the formula: $\mathrm{A}=\pi \mathrm{r}^{2}$. To convert the data obtained in $\mathrm{kgf} / \mathrm{cm}^{2}$ into $\mathrm{MPa}$, values were divided by 9.8 .

Fracture strength was assessed and the values of stress and fracture strength were submitted to statistical analysis (2-way ANOVA, Bonferroni test, $\mathrm{p}<.05$ ) using GraphPad Prism software (GraphPad Software Inc, La Jolla, California, USA). The fracture strength of each group was also evaluated by a 2-parameter Weibull distribution (95\% confidence interval) to analyze the distribution parameters of the fatigue resistance of the materials.

\section{Results}

Figure 4 ( $a$ and $b$ ) and Figure 5 ( $a$ and $b$ ) show stress generated by the cylinders and implants, respectively, when photoelastic analysis was performed.

The comparison of mean stress (2-way ANOVA, Bonferroni, $\mathrm{p}<.05$ ) for Ti and $\mathrm{Zr}$ cylinders can be seen in Table 1 . The results indicate that no statistically significant difference $(p>.05)$ was found between the forces generated when the materials were compared, irrespective of the point analyzed.

When the stress values within the same material were compared, no statistically significant difference $(p>.05)$ was found among the points of the $\mathrm{Zr}$ cylinders. For Ti cylinders, highest stress occurred at point 3 , which was only similar to point $2(p>.05)$ and different from the others $(p<.05)$. The same level of stress occurred between points 1 and 5 $(\mathrm{p}>.05)$ and 2 and $4(\mathrm{p}>.05)$.

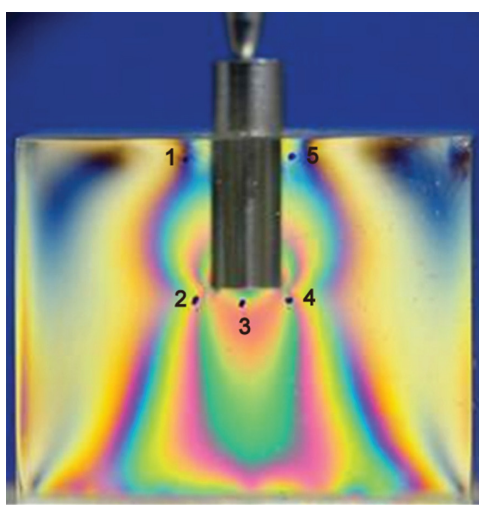

(a)

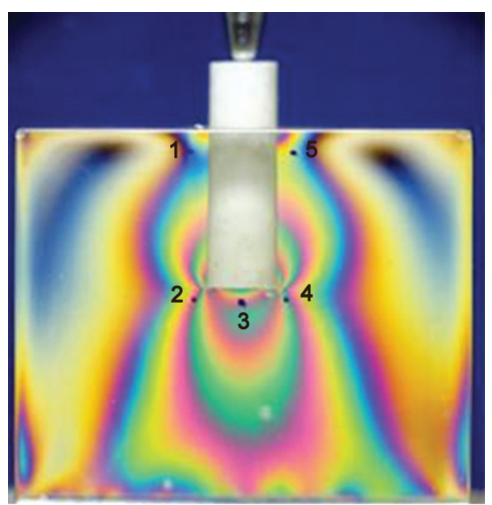

(b)

Figure 4. Comparison between photoelasticity observed in the titanium (a) and zirconia (b) cylinders under a load of $200 \mathrm{~N}$.

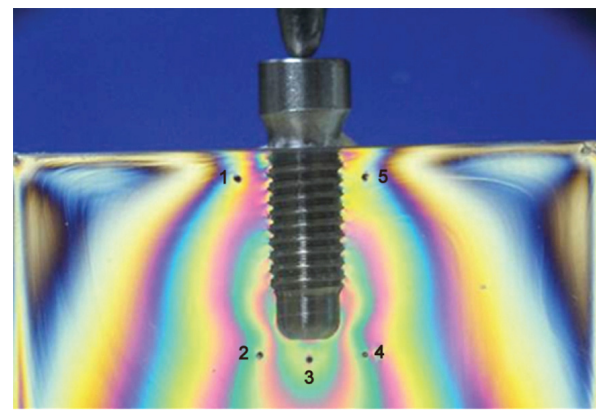

(a)

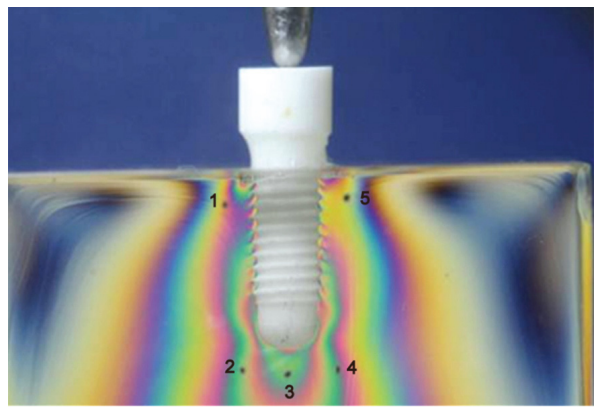

(b)

Figure 5. Comparison between photoelasticity observed in the titanium (a) and zirconia (b) implants under a load of $200 \mathrm{~N}$.

Table 1. Comparison of mean stress (standard deviation) (MPa) for titanium and zirconia cylinders (2-way ANOVA, Bonferroni, $\mathrm{p}<.05$ ).

\begin{tabular}{cccccc}
\hline Cylinders & Point 1 & Point 2 & Point 3 & Point 4 & Point 5 \\
\hline Titanium & $15.22( \pm 2.88) \mathrm{aA}$ & $24.59( \pm 1.62) \mathrm{aBC}$ & $30.84( \pm 1.36) \mathrm{aB}$ & $23.66( \pm 3.96) \mathrm{aC}$ & $15.26( \pm 1.62) \mathrm{aA}$ \\
Zirconia & $20.39( \pm 0.97) \mathrm{aA}$ & $20.25( \pm 3.34) \mathrm{aA}$ & $26.75( \pm 2.97) \mathrm{aA}$ & $20.18( \pm 2.16) \mathrm{aA}$ & $20.82( \pm 2.57) \mathrm{aA}$ \\
\hline
\end{tabular}

Same letters, lower case in column and capital letters in the line indicate no statistically significant difference $(\mathrm{p}>.05)$. 
The comparison of mean stress (2-way ANOVA, Bonferroni test, $\mathrm{p}<.05$ ) for implants is shown in Table 2. No statistically significant differences $(p>.05)$ were found between the points studied in comparison with $\mathrm{Zr}$ and $\mathrm{Ti}$, with the exception of point $3(\mathrm{p}<.05)$.

When the stress at the points of the same material were compared, it was observed that highest stress occurred at point 3 for the $\mathrm{Zr}$ implants, which showed a statistically

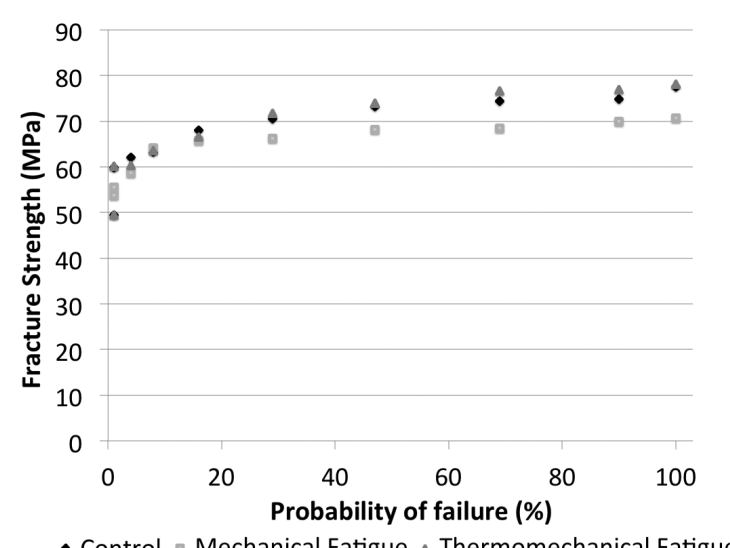

- Control $=$ Mechanical Fatigue $\triangle$ Thermomechanical Fatigue

Figure 6. The fracture strength of zirconia implants evaluated by Weibull distribution.

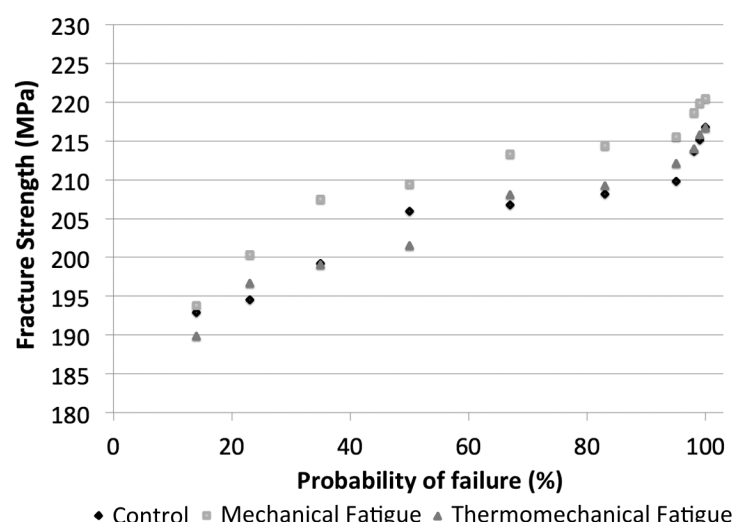

Figure 7. The fracture strength of titanium implants evaluated by Weibull distribution. significant difference $(\mathrm{p}<.05)$ in comparison with the other points. As for points 1, 2, 4, and 5, they showed no statistically significant difference $(\mathrm{p}>.05)$ among them. For the Ti implants, the point of highest stress concentration was also at point 3 with a statistically significant difference $(\mathrm{p}<.05)$ in comparison with the other groups, followed by point 2 that was statistically different $(\mathrm{p}<.05)$ when compared with the other groups, with the exception of point 4 . The stress at point 1 showed similar levels $(p>.05)$ as points 4 and 5 .

The Ti implants showed higher fracture strength than the Zr implants (2-way ANOVA, Bonferroni, p < .05) (Table 3) and a statistically significant difference $(p<.05)$ was found for all groups.

The fracture strength distributions of the specimens for $\mathrm{Zr}$ and $\mathrm{Ti}$ are shown in Figures 6 and 7, respectively, along with the Weibull parameters. The results show that $\mathrm{Zr}$ implants are more likely to fail than Ti implants. After 2 million thermomechanical cycles, Ti implants showed the highest mean fracture strength $(220 \mathrm{MPa})$, while the fracture strength of $\mathrm{Zr}$ implants was $78 \mathrm{MPa}$. When the different treatments for the same material were compared, no statistically significant difference was found $(p>.05)$ among the groups (Table 3, Figures 6 and 7).

\section{Discussion}

This study compared the stresses generated and fracture strength of $\mathrm{Zr}$ and grade $4 \mathrm{Ti}$ implants submitted to mechanical and thermomechanical fatigue, which was based on the null hypothesis that no difference would occur between the transfer of forces of the materials tested and that cyclic loading would not be able to interfere with the fracture strength of the implants. The stresses generated was analyzed using the photoelastic method and fracture strength was recorded from the application of forces on the implant positioned at an angle of $30^{\circ}$, as most zirconia implants are used in anterior areas ${ }^{13,14}$. The analyses of the results indicate that null hypotheses can be partially accepted. As for stress distribution, a statistically significant difference $(p<.05)$ was found for some of points analyzed. However, no statistically significant difference $(p>.05)$ was found for the fracture strength values when comparing the treatments to which the implants were submitted.

The photoelastic method chosen for the present research has been widely used by several authors ${ }^{15-19}$, who describe and qualify photoelasticity as being the method for analysis

Table 2. Comparison of mean stress (standard deviation) (MPa) for titanium and zirconia implants (2-way ANOVA, Bonferroni, ( $\mathrm{p}<.05)$.

\begin{tabular}{cccccc}
\hline Cylinders & Point 1 & Point 2 & Point 3 & Point 4 \\
\hline Titanium & $18.78( \pm 3.18) \mathrm{aA}$ & $25.99( \pm 1.82) \mathrm{aB}$ & $40.78( \pm 2.04) \mathrm{aC}$ & $25.13( \pm 2.08) \mathrm{aAB}$ & $16.37( \pm 1.97) \mathrm{aA}$ \\
Zirconia & $15.65( \pm 2.84) \mathrm{aA}$ & $21.90( \pm 2.73) \mathrm{aA}$ & $34.93( \pm 3.12) \mathrm{bB}$ & $22.26( \pm 1.94) \mathrm{aA}$ & $15.65( \pm 1.84) \mathrm{aA}$ \\
\hline
\end{tabular}

Same letters, lower case in column and capital letters in the line indicate no statistically significant difference $(\mathrm{p}>.05)$.

Table 3. Mean (standard deviation) stress $(\mathrm{MPa})$ of fracture strength of zirconia and titanium implants.

\begin{tabular}{crrr}
\hline Implants & Control & Mechanical fatigue & Thermomechanical fatigue \\
\hline Titanium & $206.29( \pm 8.35) \mathrm{aA}$ & $211.34( \pm 8.74) \mathrm{aA}$ & $206.29( \pm 9.08) \mathrm{aA}$ \\
Zirconia & $67.32( \pm 8.67) \mathrm{bA}$ & $64.11( \pm 6.04) \mathrm{bA}$ & $67.72( \pm 9.38) \mathrm{bA}$ \\
\hline
\end{tabular}

Same letters, lower case in column and capital letters in the line indicate no statistically significant difference $(p>.05)$. 
that allows the visualization of the stress on the bodies, which can be measured and photographed.

Some studies ${ }^{20,21}$ show that implant design is an important aspect in stress distribution and stress concentration, which can be minimized by the design. Thus, threaded implants present more favorable stress distribution than the non-threaded ones and these findings corroborate the data collected in the present study that shows that implants presented a more uniform stress distribution when compared with the cylinders of the same material.

In a qualitative analysis of stresses transmission applied on the cylinders (without spirals), despite the difference in elastic modulus of titanium and zirconium $(120 \mathrm{GPa}$ and $210 \mathrm{GPa}$ respectively $)^{22,23}$, it was found that $\mathrm{Zr}$ and $\mathrm{Ti}$ showed the same pattern of force distribution, but at different intensities. The intensity of stress was evaluated using the quantitative method and, according to the results presented, it may be stated that no statistically significant difference was found among the 5 points assessed in comparison with $\mathrm{Zr}$ and $\mathrm{Ti}$.

When the qualitatively transfer of stresses of the Ti and Zr implants was analyzed, a greater evidence of equivalence was noted mainly due to the removal of sharp angles at the apex inserted in the photoelastic resin, as found in the previous comparative analysis of the cylinders, and due to the presence of the spirals along the part that distributes forces more evenly along the implant post without stress concentration at the apex ${ }^{18,20,24}$.

Some studies ${ }^{25,26}$ reported a difference in transfer of stress around implants according to the type of implant material used. Other authors observed that stress transmitted to the bone is almost independent of the type of material used ${ }^{27-29}$, which is in agreement with the results of the present study that found a statistically significant difference $(p<.05)$ only at one of the five points of stress assessed comparatively between the $\mathrm{Zr}$ and $\mathrm{Ti}$ implants.

Sertgö $\mathrm{z}^{29}$ concluded that the use of resilient materials to fabricate structures overloads the prosthetic screws, increasing the chances of system failure. Stegaroiu et al. ${ }^{30}$ and Menani et al. ${ }^{31}$ concluded that the use of ceramic prostheses decreases the amount of stress transmitted to the implants. Thus, the use of ceramic materials would be beneficial for implant survival when taking into account transfer of stress, which confirms the findings of the present study that found that the transfer of force of $\mathrm{Zr}$ implants was lower than the stress transmitted by metal implants.

\section{References}

1. Chaturvedi T. Allergy related to dental implant and its clinical significance. Clinical, Cosmetic and Investigational Dentistry. 2013; 5:57-61. http://dx.doi.org/10.2147/CCIDE.S35170. PMid:23990733.

2. Glauser R, Sailer I, Wohlwend A, Studer S, Schibli M and Schärer P. Experimental zirconia abutments for implantsupported single-tooth restorations in esthetically demanding regions: 4-year results of a prospective clinical study. The International Journal of Prosthodontics. 2004; 17(3):285-290. PMid:15237873.

3. Kohal RJ, Att W, Bächle M and Butz F. Ceramic abutments and ceramic oral implants. An update. Periodontology 2000.
The aging method selected for this study is closer to clinical reality with temperatures that did not exceed $50{ }^{\circ} \mathrm{C}$ and chewing simulation ${ }^{14,32}$. The mean values, for normal chewing force in the area of posterior teeth, ranges from $250 \mathrm{~N}$ to $400 \mathrm{~N}$, while the range of force for anterior teeth is from $110 \mathrm{~N}$ to $170 \mathrm{~N}^{12}$. In the present study, force of $133 \mathrm{~N}$ was used during mechanical cycling ${ }^{11}$, which is within the range of bite force in the area of anterior teeth in patients with normal occlusion ${ }^{12}$.

Considering all mean values after fatigue treatments, the $\mathrm{Zr}$ implants fracture strength found in this study was $56 \mathrm{kgf}$, which was higher than the load exerted on the anterior area both for chewing and maximum anterior bite force ${ }^{14}$.

With temperatures ranging from $5{ }^{\circ} \mathrm{C}, 37^{\circ} \mathrm{C}$ and $55^{\circ} \mathrm{C}$, no power supply is sufficient to destabilize the tetragonal phase in zirconia and transform it into a monoclinic phase $\mathrm{e}^{13,14}$, which could lead to reduction in strength, hardness and density, followed by micro- and macro-cracks and surface roughness $^{33}$, which justifies the similar significant results $(\mathrm{p}>.05)$ among the groups studied. Thus, thermal or thermomechanical cycling did not play a decisive role in the properties of the materials studied, as shown by Weibull distribution (Figure 6 and 7).

Titanium presented higher fracture strength than the $\mathrm{Zr}$ implants with a statistically significant difference $(p<.05)$ for all groups (Table 3 ). One reason for the low fracture strength of the $\mathrm{Zr}$ implants may be due to the surface machining process of the material to obtain the implant which may cause surface cracks leading to strength degradation of the material ${ }^{34-37}$. Another reason for the disparity among the results in fracture strength of $\mathrm{Zr}$ and $\mathrm{Ti}$ implants are the physical, chemical and mechanical properties of each of these materials.

Based on the methodology used in this study and the results obtained and discussed, it can be concluded that stress distribution was similar for $\mathrm{Zr}$ and $\mathrm{Ti}$ and mechanical and thermomechanical fatigue did not influence fracture strength of the implants tested, however, further studies need to be conducted to understand the biological, functional and aesthetic aspects of zirconia implants before they can be recommended for daily practice.

\section{Acknowledgements}

The authors would like to thank FAPESP (Grant $n^{\circ} 2010 / 12072-8$ ) for the financial support.

2008; 47(1):224-243. http://dx.doi.org/10.1111/j.16000757.2007.00243.x. PMid:18412584.

4. Andreiotelli M, Wenz HJ and Kohal R-J. Are ceramic implants a viable alternative to titanium implants? A systematic literature review. Clinical Oral Implants Research. 2009; 20(Suppl 4):32-47. http://dx.doi.org/10.1111/j.1600-0501.2009.01785.x. PMid:19663947.

5. Assal PA. The osseointegration of zirconia dental implants. Schweizer Monatsschrift Zahnmed. 2013; 123(7-8):644-654. PMid:23965893.

6. Çaglar A, Bal BT, Karakoca S, Aydın C, Yılmaz H and Sarısoy $\mathrm{S}$. Three-dimensional finite element analysis of titanium and yttrium-stabilized zirconium dioxide abutments and implants. 
The International Journal of Oral \& Maxillofacial Implants. 2011; 26(5):961-969. PMid:22010077.

7. Borgonovo AE, Censi R, Vavassori V, Dolci M, Calvo-Guirado JL, Delgado Ruiz RA, et al. Evaluation of the success criteria for zirconia dental implants: a four-year clinical and radiological study. International Journal of Dentistry. 2013; 2013:463073. http://dx.doi.org/10.1155/2013/463073. PMid:24065992.

8. Borgonovo AE, Vavassori V, Censi R, Calvo JL and Re D. Behavior of endosseous one-piece yttrium stabilized zirconia dental implants placed in posterior areas. Minerva Stomatologica. 2013; 62(7-8):247-257. PMid:24002561.

9. Manicone PF, Rossi Iommetti P, Raffaelli L, Paolantonio M, Rossi G, Berardi D, et al. Biological considerations on the use of zirconia for dental devices. International Journal of Immunopathology and Pharmacology. 2007;20(1, Suppl 1):9-12. PMid:17897494.

10. Montarou CC and Gaylord TK. Two-wave-plate compensator method for single-point retardation measurements. Applied Optics. 2004; 43(36):6580-6595. http://dx.doi.org/10.1364/ AO.43.006580. PMid:15646778.

11. International Organization for Standardization - ISO. ISO 14081: dentistry implants: dynamic fatigue test for endosseous dental implants. 2nd ed. Geneva; 2007.

12. Fontijn-Tekamp FA, Slagter AP, Van Der Bilt A, Van 'T Hof MA, Witter DJ, Kalk W, et al. Biting and chewing in overdentures, full dentures, and natural dentitions. Journal of Dental Research. 2000; 79(7):1519-1524. http://dx.doi.org/10.1177/002203450 00790071501 . PMid:11005738.

13. Kohal RJ, Finke HC and Klaus G. Stability of prototype twopiece zirconia and titanium implants after artificial aging: an in vitro pilot study. Clinical Implant Dentistry and Related Research. 2009; 11(4):323-329. http://dx.doi.org/10.1111/j.17088208.2008.00116.x. PMid:18783418.

14. Andreiotelli M and Kohal R-J. Fracture strength of zirconia implants after artificial aging. Clinical Implant Dentistry and Related Research. 2009; 11(2):158-166. http://dx.doi. org/10.1111/j.1708-8208.2008.00105.x. PMid:18657150.

15. Brodsky JF, Caputo AA and Furstman LL. Root tipping: a photoelastic-histopathologic correlation. American Journal of Orthodontics. 1975; 67(1):1-10. http://dx.doi.org/10.1016/00029416(75)90124-4. PMid:803022.

16. Kim HC, Essaki S, Kameyama T and Yamamoto K. Photoelastic analysis of internal screw fixation after sagittal split ramus osteotomy. Journal of Cranio-Maxillo-Facial Surgery. 1993; 21(6):266-270. http://dx.doi.org/10.1016/S1010-5182(05)800459. PMid:8227377.

17. Pellizzer EP, Carli RI, Falcón-Antenucci RM, Verri FR, Goiato MC and Villa LM. Photoelastic analysis of stress distribution with different implant systems. The Journal of Oral Implantology. 2014; 40(2):117-122. http://dx.doi.org/10.1563/ AAID-JOI-D-11-00138. PMid:22208909.

18. Ozkir SE and Terzioglu H. Macro design effects on stress distribution around implants: a photoelastic stress analysis. Indian Journal of Dental Research. 2012; 23(5):603-607. http:// dx.doi.org/10.4103/0970-9290.107346. PMid:23422604.

19. Lee JI, Lee Y, Kim NY, Kim YL and Cho HW. A photoelastic stress analysis of screw- and cement-retained implant prostheses with marginal gaps. Clinical Implant Dentistry and Related Research. 2013; 15(5):735-749. PMid:23927066.

20. Haraldson T. A photoelastic study of some biomechanical factors affecting the anchorage of osseointegrated implants in the jaw. Scandinavian Journal of Plastic and Reconstructive Surgery. 1980; 14(3):209-214. http://dx.doi.org/10.3109/02844318009106712. PMid:7209405.

21. Fuh LJ, Hsu JT, Huang HL, Chen MY and Shen YW. Biomechanical investigation of thread designs and interface conditions of zirconia and titanium dental implants with bone: three-dimensional numeric analysis. The International Journal of Oral \& Maxillofacial Implants. 2013; 28(2):e64-e71. http:// dx.doi.org/10.11607/jomi.2131. PMid:23527370.

22. Chevalier J, Gremillard L and Deville S. Low-temperature degradation of zirconia and implications for biomedical implants. Annual Review of Materials Research. 2007; 37(1):1-32. http:// dx.doi.org/10.1146/annurev.matsci.37.052506.084250.

23. Denry I and Kelly JR. State of the art of zirconia for dental applications. Dental Materials. 2008; 24(3):299-307. http:// dx.doi.org/10.1016/j.dental.2007.05.007. PMid:17659331.

24. Cehreli M, Duyck J, De Cooman M, Puers R and Naert I. Implant design and interface force transfer. A photoelastic and strain-gauge analysis. Clinical Oral Implants Research. 2004; 15(2):249-257. http://dx.doi.org/10.1111/j.1600-0501.2004.00979.x. PMid:15008938.

25. Skalak R. Biomechanical considerations in osseointegrated prostheses. The Journal of Prosthetic Dentistry. 1983; 49(6):843848. http://dx.doi.org/10.1016/0022-3913(83)90361-X. PMid:6576140.

26. Ciftçi $Y$ and Canay S. Stress distribution on the metal framework of the implant-supported fixed prosthesis using different veneering materials. The International Journal of Prosthodontics. 2001; 14(5):406-411. PMid:12066633.

27. Juodzbalys G, Kubilius R, Eidukynas V and Raustia AM. Stress distribution in bone: single-unit implant prostheses veneered with porcelain or a new composite material. Implant Dentistry. 2005; 14(2):166-175. http://dx.doi.org/10.1097/01. id.0000165030.59555.2c. PMid:15968189.

28. Markarian RA, Ueda C, Sendyk CL, Laganá DC and Souza RM. Stress distribution after installation of fixed frameworks with marginal gaps over angled and parallel implants: a photoelastic analysis. Journal of Prosthodontics. 2007; 16(2):117-122. http:// dx.doi.org/10.1111/j.1532-849X.2007.00161.x. PMid:17362421.

29. Sertgöz A. Finite element analysis study of the effect of superstructure material on stress distribution in an implantsupported fixed prosthesis. The International Journal of Prosthodontics. 1997; 10(1):19-27. PMid:9484066.

30. Stegaroiu R, Kusakari H, Nishiyama S and Miyakawa O. Influence of prosthesis material on stress distribution in bone and implant: a 3-dimensional finite element analysis. The International Journal of Oral \& Maxillofacial Implants. 1998; 13(6):781-790. PMid:9857588.

31. Menani LR, Tiossi R, de Torres ÉM, Ribeiro RF and de Almeida RP. Photoelastic stress analysis of different designs of cementretained fixed partial dentures on Morse taper oral implants. The Journal of Craniofacial Surgery. 2011; 22(2):674-678. http:// dx.doi.org/10.1097/SCS.0b013e3182074571. PMid:21415635.

32. Silva NR, Coelho PG, Fernandes CA, Navarro JM, Dias RA and Thompson VP. Reliability of one-piece ceramic implant. Journal of Biomedical Materials Research. 2009; 88(2):419426. http://dx.doi.org/10.1002/jbm.b.31113. PMid:18491412.

33. Swab JJ. Low temperature degradation of Y-TZP materials. Journal of Materials Science. 1991; 26(24):6706-6714. http:// dx.doi.org/10.1007/BF02402664.

34. Kosmac T, Oblak C, Jevnikar P, Funduk N and Marion L. Strength and reliability of surface treated Y-TZP dental ceramics. Journal of Biomedical Materials Research. 2000; 53(4):304-313. http://dx.doi.org/10.1002/1097-4636(2000)53:4<304::AIDJBM4>3.0.CO;2-S. PMid:10898871.

35. Luthardt RG, Holzhüter M, Sandkuhl O, Herold V, Schnapp JD, Kuhlisch E, et al. Reliability and properties of ground Y-TZP-zirconia ceramics. Journal of Dental Research. 2002; 81(7):487-491. http://dx.doi.org/10.1177/154405910208100711. PMid:12161462. 
36. Yin L, Jahanmir S and Ives LK. Abrasive machining of porcelain and zirconia with a dental hand piece. Wear. 2003; 255(7-12):975-989. http://dx.doi.org/10.1016/S00431648(03)00195-9.
37. Guazzato M, Quach L, Albakry M and Swain MV. Influence of surface and heat treatments on the flexural strength of Y-TZP dental ceramic. Journal of Dentistry. 2005; 33(1):9-18. http:// dx.doi.org/10.1016/j.jdent.2004.07.001. PMid:15652163. 